\title{
PENGARUH ROCE DAN ROE TERHADAP DIVIDEND YIELD
}

\author{
Shifa Miarti Aziza \\ Manajemen Keuangan Syariah, UIN Sunan Gunung Djati Bandung \\ shifamiartia@gmail.com \\ Deni Kamaludin Yusup \\ Manajemen Keuangan Syariah, UIN Sunan Gunung Djati Bandung \\ dkyusup@uinsgd.ac.id \\ Vinna Sri Yuniarti \\ Manajemen Keuangan Syariah, UIN Sunan Gunung Djati Bandung \\ vinnasriyuniarti@uinsgd.ac.id
}

\begin{abstract}
Abstrak
Tujuan utama seorang investor dalam berivestasi adalah dividen. Indikator yang digunakan untuk mengukur kebijakan dividen adalah Dividend Yield. Rasio profitabilitas yang diproyeksikan melalui Return on Capital Employed (ROCE) dan Return on Equity (ROE) diindikasikan mempengaruhi Dividen Yield. Tujuan dari penelitian ini adalah menganalisis pengaruh ROCE dan ROE terhadap Dividend Yield pada PT. Waskita Karya, Tbk. Periode 2010-2019. Metode penelitian ini yaitu metode deskriptif verifikatif dengan pendekatan kuantitatif. Data penelitian bersumber dari data sekunder yaitu laporan keuangan tahunan yang telah dipublikasikan oleh perusahaan. Kemudian, analisis data menggunakan analisis asumsi klasik, statistik deskriptif, dan analisis kuantitatif. Hasil penelitian menunjukkan bahwa secara parsial ROCE berpengaruh terhadap dividend yield dengan kontribusi sebesar 59.1 persen, ROE berpengaruh terhadap dividend yield dengan kontribusi sebesar 63.9 persen. Dan secara simultan ROCE dan ROE berpengaruh terhadap dividen yield dengan kontribusi sebesar sebesar $65.2 \%$ sisanya sebesar $34.8 \%$ dipengaruhi oleh faktor lain di luar penelitian.
\end{abstract}

Kata Kunci: Return on Capital Employed, Return on Equity, Dividend Yield.

\begin{abstract}
The main purpose of an investor in investing is dividends. The indicator used to measure dividend policy is Dividend Yield. Profitability ratios projected through Return on Capital Employed (ROCE) and Return on Equity (ROE) are indicated to affect Dividend Yield. The purpose of this study was to analyze the effect of ROCE and ROE on Dividend Yield at PT. Waskita Karya, Tbk. 2010-2019 period. This research method is descriptive verification method with a quantitative approach. The research data comes from secondary data, namely the annual financial reports that have been published by the company. Then, data analysis used classical assumption analysis, descriptive statistics, and quantitative analysis. The results showed that partially ROCE had an effect on dividend yield with a contribution of 59.1 percent, $\mathrm{ROE}$ had an effect on dividend yield with a contribution of 63.9 percent. And simultaneously ROCE and ROE affect dividend yield with a contribution of $65.2 \%$, the remaining $34.8 \%$ is influenced by other factors outside the study.
\end{abstract}

Keywords: Return on Capital Employed, Return on Equity, Dividend Yield. 


\section{Pendahuluan}

Investasi memiliki peran yang besar dalam sumbangsihnya pada perkembangan perekonomian di Indonesia. Pendapatan nasional dan investasi memiliki hubungan dengan korelasi positif, di mana jika investasi maka pendapatan nasional juga akan naik dan berlaku sebaliknya (Arrohmah \& Soelistyo, 2010). Pembentukan modal menurut Sulistiwati (2012) merupakan komponen penting dalam meningkatkan pembangunan dan pertumbuhan ekonomi di Indonesia. Modal tersebut berasal dari para investor baik perushaan maupun individu nantinya akan membantu dalam menambah stock modal yang dibutuhkan. Tujuan dari pembentukan stock modal tersebut adalah untuk proses produksi sehingga akan menghasilkan barang dan jasa yang dapat dikonsumsi oleh masyarakat.

Dalam dunia investasi, penanam modal disebut investor. Investor dapat berupa orang perorangan atau lembaga domestik maupun non domestik. Ketika seorang investor menanamkan modalnya pada suatu saham perusahaan maka hal itu telah melalui berbagai pertimbangan. Pertimbangan ini beruapa melihat fluktuasi harga saham, kinerja keuangan, dan berbagai risiko yang mungkin terjadi di masa mendatang. Pertimbangan ini diperlukan agar investor dapat menaksir keuntungan yang didapatkan.Dengan demikian, akan terdapat dua permasalahan yang dihadapi oleh para investor yaitu perhitungan nilai yang diharapkan dan mengenai pengukuran penyebaran nilai (Suteja \& Gunardi, 2016). Tujuan utama investor dalam berinvestasi adalah mendapatkan return saham, dimana hasilnya dalam bentuk dividen dan capital gain (loss). Dividen adalah hasil yang didapatkan oleh investor atas penanaman modalnya. Sementara capital gain adalah selisih dari harga investasi saat ini yang lebih tinggi dari periode sebelumnya (Carlo Aldo, 2014).

Bagi investor laporan keuangan peusahaan merupakan salah satu sumber informasi penting (Dewi, 2014). Di dalam laporan keuangan memiliki informasi khusus dari keempat jenis laporan keuangan yang ada, neraca, arus kas, laba rugi dan perubahan modal. Laporan-laporan keuangan tersebut akan dianalisis untuk dilihat bagaimana kinerja dari perusahaan tersebut. Analisis laporan keuangan ini menggunakan berbagai metode untuk melihat hubungan masingmasing akun dan berbagai jenis rasio yang terdapat dalam laporan keuangan tersebut. Dengan menganalisis laporan keuangan akan memudahkan investor dalam membuat keputusan dalam melakukan investasi.

Terdapat lima rasio keuangan yang digunakan untuk menganalisis kinerja perusahaan, yaitu rasio likuiditas, rasio solvabilitas, rasio profitabilitas, rasio aktivitas dan rasio pasar (Ang, 2010). Rasio keuangan yang digunakan dalam penulisan ini adalah rasio profitabilitas dan rasio pasar. Rasio profitabilitas ini digunakan sebagai pencatatan keuangan yang akan dinilai oleh investor untuk mengukur dan menilai kemampuan perusahaan dalam menghasilkan laba yang akan diterima dan mengetahui kemampuan perusahaan dalam membayar utang berdasarkan besaran laba yang dimiliki oleh perusahaan.

Sedangkan rasio pasar dapat membantu investor dalam mencari saham yang memiliki potensi keuntungan dividen yang tinggi sebelum melakukan penanaman modal. Tingginya hasil presentase rasio pasar maka semakin besar juga kepercayaan investor dalam menanamkan modalnya untuk perolehan investasi yang akan didapatkannya di masa yang akan datang. Tentunya hal ini akan berpengaruh kepada jumlah saham beredar dan return sabam yang akan diterima oleh investor (Rusydina \& Praptoyo, 2017).

Dalam rasio profitabilitas terdapat beberapa rasio yang digunakan untuk mengukur laba yang akan diperoleh oleh investor dalam berinvestasi di antaranya adalah Return on Capital Employed (ROCE) dan Return on Equity (ROE) (Masyitah \& Harahap, 2018). Kedua rasio ini 
merupakan alat yang berharga untuk mengukur efisiensi operasional perusahaan dan potensi yang dihasilkan untuk pertumbuhan nilai di masa depan. Keduanya sering digunakan secara bersama untuk menghasilkan evaluasi kinerja perusahaan. Return on Capital Employed (ROCE) adalah ukuran yang digunakan untuk mengetahui seberapa efisien suatu perusahaan dalam mengelola modal kerjanya untuk menghasilkan laba. Sedangkan Return on Equity (ROE) merupakan persentase ekspresi dari laba bersih perusahaan untuk mengembalikan nilai kepada pemegang saham (Aprilia, 2012).

Pemegang saham tentunya akan mendapatkan keuntungan atas sahamnya. Keuntungan yang didapat oleh investor disebut juga dengan dividen. Dividen merupakan laba yang diberikan kepada para pemegang saham dari perusahaan. Indikator yang digunakan untuk mengukur kebijakan dividen adalah Dividend Yield (DY). Dividend Yield adalah tingkat keuntungan yang diberikan oleh perusahaan yang perhitungannya dilakukan dengan cara Dividen per saham dibagi harga pasar saham. Dividend Yield memiliki pengaruh yang positif terhadap rasio profitabilitas (Prakoso \& Chabachib, 2016). Jika Return on Capital Employed (ROCE) dan Return on Equity (ROE) semakin tinggi maka akan mengindikasikan harga saham yang tinggi dan ketika Return on Capital Employed (ROCE) dan Return on Equity (ROE) rendah mengindikasikan harga saham yang rendah (Rahmadewi \& Abudanti, 2018). Saat harga saham turun maka Dividend Yield akan turun. Sebaliknya, saat harga saham naik maka Dividend Yield akan naik.

Tabel 1. ROCE, ROE dan Dividend Yield (DY) di PT. Waskita Karya, Tbk.

Data dalam \%

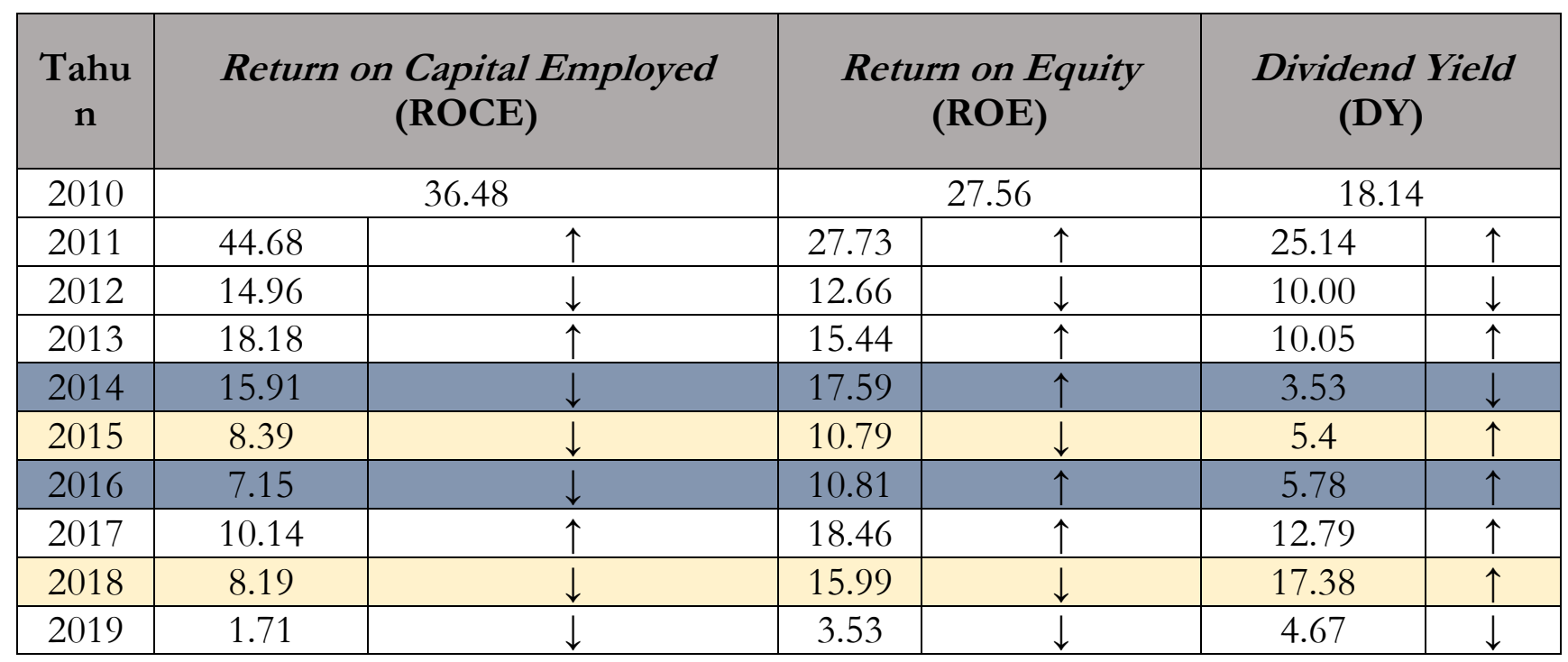

Sumber: Data empiris yang diolah dari laporan Tahunan PT. Waskita Karya, Tbk.

Keterangan :

$\uparrow \quad$ : Mengalami peningkatan dari tahun sebelumnya

$\downarrow \quad$ : Mengalami penurunan dari tahun sebelumnya

Mengacu pada tabel di atas, terlihat bahwa Return on Capital Employed (ROCE), Return on Equity (ROE) dan Dividend Yield (DY) mengalami fluktuasi setiap tahunnya. Peran Return on Capital Employed (ROCE) sangat berguna bagi perusahaan untuk menambah profit karena ROCE mengindikasikan seberapa baik kinerja perusahaan dalam memanfaatkan modalnya untuk memperoleh profit yang maksimal (Herlina, 2013) Selain peran penting Return on Capital Employed (ROCE), Return on Equity (ROE) merupakan rasio profitabilitas yang digunakan untuk mengukur besarnya tingkat pengembalian modal perusahaan. Perusahaan yang memiliki 
profitabilitas tinggi tentu akan menarik minat investor untuk menanamkan modalnya dengan harapan akan mendapatkan keuntungan yang tinggi.

Return on Equity (ROE) yang semakin besar menunjukkan kinerja perusahaan semakin baik. Saat kinerja perusahaan semakin baik maka akan berpengaruh terhadap tingkat pengembalian (Income Return) pendapatan juga akan semakin besar. Sebaliknya, semakin kecil Return on Equity (ROE) maka akan menunjukkan kinerja perusahaan yang semakin buruk, saat kinerja perusahaan semakin buruk maka akan berpengaruh terhadap tingkat pengembalian (Income Return) pendapatan juga akan semakin kecil. Besarnya pengembalian pendapatan (Income Return) akan berpengaruh terhadap penggambaran Dividend Yield yang akan didapatkan investor atas sejumlah uang yang mereka investasikan (Khuniarji, 2013).

Berdasarkan pemaparan tersebut, ada ketidak sesuaian antara teori dan data dilapangan. Dari data table diatas, menunjukkan bahwa tidak selalu kenaikan Return on Capital Employed (ROCE) dan Return on Equity (ROE) akan diikuti dengan kenaikan Dividend Yield (DY) pula, begitupun sebaliknya. Pada tahun 2014 Return on Capital Employed (ROCE) dan Dividend Yield (DY) mengalami penurunan, tetapi Return on Equity (ROE) mengalami peningkatan. Pada tahun 2015 dan 2018 Return on Capital Employed (ROCE) dan Return on Equity (ROE) mengalami penurunan, tetapi Dividend Yield (DY) mengalami peningkatan. Pada tahun 2016 Return on Capital Employed (ROCE) mengalami penurunan, tetapi Return on Equity (ROE) dan Dividend Yield (DY) mengalami peningkatan.

Maka dari itu, artikel ini bertujuan untuk menganalisis pengaruh rasio profitabilitas yang dipresentasikan oleh Return on Capital Employed (ROCE) dan Return on Equity (ROE) terhadap Dividend Yield (DY) pada PT. Waskita Karya, Tbk yang terdaftar di Jakarta Islamic Index (JII) pada periode 2010-2019. Berdasarkan latar belakang masalah dan tujuan penelitian ini, maka dibuatlah sebuah hipotesis. Hipotesis merupakan jawaban sementara atas permasalahan yang terdapat pada rumusan masalah penelitian. Berdasarkan kajian teoritis yang telah diuraikan diatas maka hipotesis dalam penelitian ini adalah:

1. Return on Capital Employed (ROCE) terhadap Dividend Yield (DY)

$\mathrm{H}_{\mathrm{o}}=\mathrm{ROCE}$ secara parsial tidak berpengaruh terhadap Dividend Yield.

$\mathrm{H}_{\mathrm{a}}=\mathrm{ROCE}$ secara parsial berpengaruh terhadap Dividend Yield.

2. Return on Equity (ROE) terhadap Dividend Yield (DY)

$\mathrm{H}_{\mathrm{o}}=\mathrm{ROE}$ secara parsial tidak berpengaruh terhadap Dividend Yield.

$\mathrm{H}_{\mathrm{a}}=\mathrm{ROE}$ secara parsial berpengaruh terhadap Dividend Yield.

3. Return on Capital Employed (ROCE) dan Return on Equity (ROE) terhadap Dividend Yield (DY)

$\mathrm{H}_{0}=\mathrm{ROCE}$ dan ROE secara simultan tidak berpengaruh terhadap Dividend Yield.

$\mathrm{H}_{\mathrm{a}}=\mathrm{ROCE}$ dan ROE secara simultan berpengaruh terhadap Dividend Yield .

\section{$2 \quad$ Metode}

Metode dan pendekatan yang digunakan dalam penelitian ini yaitu metode deskriptif dengan pendekatan kuantitatif. Penelitian kuantitatif ini menjelaskan hubungan antara variabel bebas dengan variabel terikat. Objek penelitian yang digunakan adalah PT. Waskita Karya, Tbk. Data yang digunakan merupakan data sekunder, dimana data diperoleh dari laporan keuangan tahunan yang telah dipublikasikan dalam website resmi perusahaan. Analisis data menggunakan analisis regresi linier, analisis korelasi, analisis koefisien determinasi dan uji hipotesis lalu diolah dengan bantuan software SPSS. Sebelum melakukan analisis regresi, terlebih dahulu melakukan uji asumsi klasik. 

berikut.

Masing-masing variabel yang terdapat dalam penelitian ini dapat dilihat pada tabel Tabel 2. Operasionalisasi Variabel Penelitian

\begin{tabular}{|c|c|c|c|c|}
\hline Variabel & Definisi & Indikator & Rumus & Skala \\
\hline $\begin{array}{l}\text { Return on } \\
\text { Capital } \\
\text { Employed } \\
\text { (ROCE) }\end{array}$ & $\begin{array}{l}\text { Return on Capital } \\
\text { Employed (ROCE) } \\
\text { merupakan indikator } \\
\text { seberapa baiknya } \\
\text { perusahaan dalam } \\
\text { memanfaatkan } \\
\text { modal untuk } \\
\text { menghasilkan } \\
\text { pendapatan (Herlina, } \\
\text { 2013) }\end{array}$ & $\begin{array}{l}\text { - Earning } \\
\text { Before } \\
\text { Interest } \\
\text { and Tax. } \\
\text { - Total } \\
\text { Asset } \\
\text { - Current } \\
\text { Liabilities }\end{array}$ & $\begin{array}{c}\text { Return on Capital Employed } \\
(\mathrm{ROCE})= \\
\text { EBIT } \\
\text { (Total Asset-Current Liabilities) }\end{array}$ & Rasio \\
\hline $\begin{array}{l}\text { Return on } \\
\text { Equity (ROE) }\end{array}$ & $\begin{array}{l}\text { Return on Equity } \\
\text { (ROE) adalah rasio } \\
\text { yang menunjukkan } \\
\text { seberapa besar } \\
\text { kontribusi modal } \\
\text { dalam menciptakan } \\
\text { laba bersih (Egam, } \\
\text { Ilat, \& Pangerapan, } \\
\text { 2017) }\end{array}$ & $\begin{array}{l}\text { - Earning } \\
\text { After Tax } \\
\text {-Total } \\
\text { Equity }\end{array}$ & $\begin{array}{l}\text { Return On Equity (ROE) } \\
=\frac{\text { Earning after tax }}{\text { Total Equity }}\end{array}$ & Rasio \\
\hline $\begin{array}{l}\text { Dividend Yield } \\
\text { (DY) }\end{array}$ & $\begin{array}{l}\text { Dividend Yield adalah } \\
\text { rasio yang } \\
\text { menentukan } \\
\text { seberapa besar suatu } \\
\text { perusahaan dalam } \\
\text { membandingkan } \\
\text { dividen kepada } \\
\text { pemegang saham } \\
\text { dilihat dari harga } \\
\text { sahamnya saat ini } \\
\text { (Hendarata, 2018) }\end{array}$ & $\begin{array}{l}\text { - Dividen } \\
\text { Per Share } \\
\text { - Market } \\
\text { Price }\end{array}$ & $=\frac{\begin{array}{r}\text { Dividend Yield } \\
\text { Dividen Per Share }\end{array}}{\text { Market Price }}$ & Rasio \\
\hline
\end{tabular}

\section{Hasil dan Pembahasan \\ Hasil Penelitian}

Hasil penelitian merupakan bagian yang menyajikan bagian generik dan uraian data yang ditemukan berdasarkan output dalam penelitian. Hasil penelitian ini yaitu mengenai profil perusahaan PT. Waskita Karya Tbk, analisis asumsi klasik, analisis deskriptif, analisis kuantitatif dan analisis uji hipotesis yang di uji dengan alat statistik yaitu Software SPSS for Windows V.20.0.

\subsection{Uji Asumsi Klasik}

Uji Normalitas

Data yang normal memiliki signifikan $>0,05$. Teknik yang digunakan peneliti antara lain Normal Probability Plot dan table uji Kolmogrov-smirnov untuk memperjelas dengan angka. 
Tabel 3. Uji Normalitas

One-Sample Kolmogorov-Smirnov Test

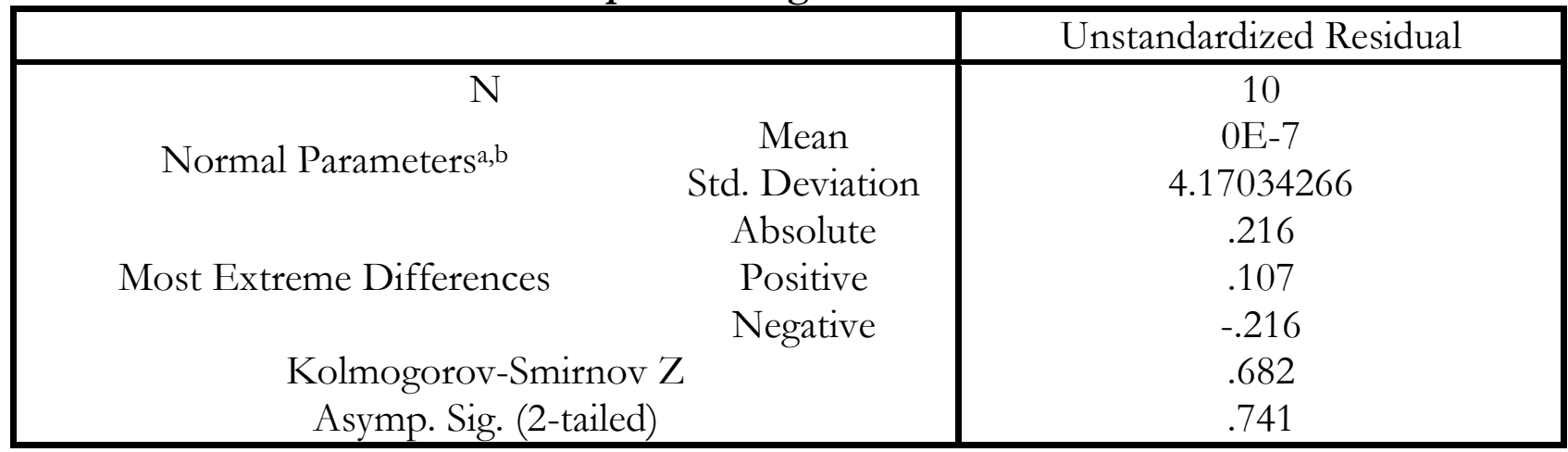

a. Test distribution is Normal.

b. Calculated from data.

Sumber: hasil output SPSS for windows versi 20

Berdasarkan tabel diatas, diperoleh nilai signifikansi sebesar $0.741>0.05$. artinya, data penelitian berdistribusi normal karena signifikansi lebih besar dari 0.05. Maka uji normalitas terpenuhi dan analisis regresi dapat dilakukan.

\section{Uji Multikolinieritas}

Uji Multikolinieritas bertujuan mengetahui ada atau tidaknya variabel bebas yang memiliki kemiripan dengan variabel bebas lain dalam satu model. Model regresi yang baik seharusnya tidak memiliki kemiripan diantara variabel bebas.

\section{Tabel 4. Uji Multikolinieritas}

Coefficients $^{\text {a }}$

\begin{tabular}{|c|c|c|c|c|c|c|c|}
\hline \multirow{2}{*}{ Model } & \multicolumn{2}{|c|}{$\begin{array}{c}\text { Unstandardized } \\
\text { Coefficients }\end{array}$} & $\begin{array}{c}\text { Standardized } \\
\text { Coefficients }\end{array}$ & \multirow{2}{*}{$\mathrm{T}$} & Sig. & \multicolumn{2}{|c|}{ Collinearity Statistics } \\
\cline { 2 - 4 } & $\mathrm{B}$ & Std. Error & Beta & & & Tolerance & VIF \\
\hline (Constant) & .440 & 4.523 & & .097 & .925 & & \\
1 ROCE (X1) & .135 & .263 & .260 & .512 & .624 & .192 & 5.198 \\
ROE (X2) & .537 & .482 & .566 & 1.114 & .302 & .192 & 5.198 \\
\hline
\end{tabular}

a. Dependent Variable: DY (Y)

Sumber: hasil output SPSS for windows versi 20

Berdasarkan hasil perhitungan uji multikolinieritas diatas diketahui bahwa nilai Variance Inflation Factor (VIF) sebesar 5.198 dan nilai tolerance sebesar 0.192. Hal ini menandakan bahwa tidak terjadi multikolinieritas antara variabel bebas dalam penelitian ini karena nilai VIF $5.198 \leq$ 10 dan nilai tolerance $0.192 \geq 0.1$. Maka dapat disimpulkan bahwa tidak terdapat multikolinieritas dan model regresi layak untuk dipakai.

\section{Uji Heteroskedasitas}

Uji Heteroskedasitas bertujuan untuk menguji apakah dalam model regresi terjadi ketidaksamaan varian dengan pengamatan yang lain. Jika model regresi terdapat pola tertentu seperti titik-titik yang membentuk pola bergelombang atau melebar maka dapat disimpulkan adanya indikasi heteroskedastisitas. Tetapi, apabila data tidak tidak membentuk pola dan titik- 
titik menyebar pada bagian atas dan bawah angka 0 dibagian sumbu $\mathrm{Y}$ dapat disimpulkan tidak adanya indikasi heteroskedastisitas.

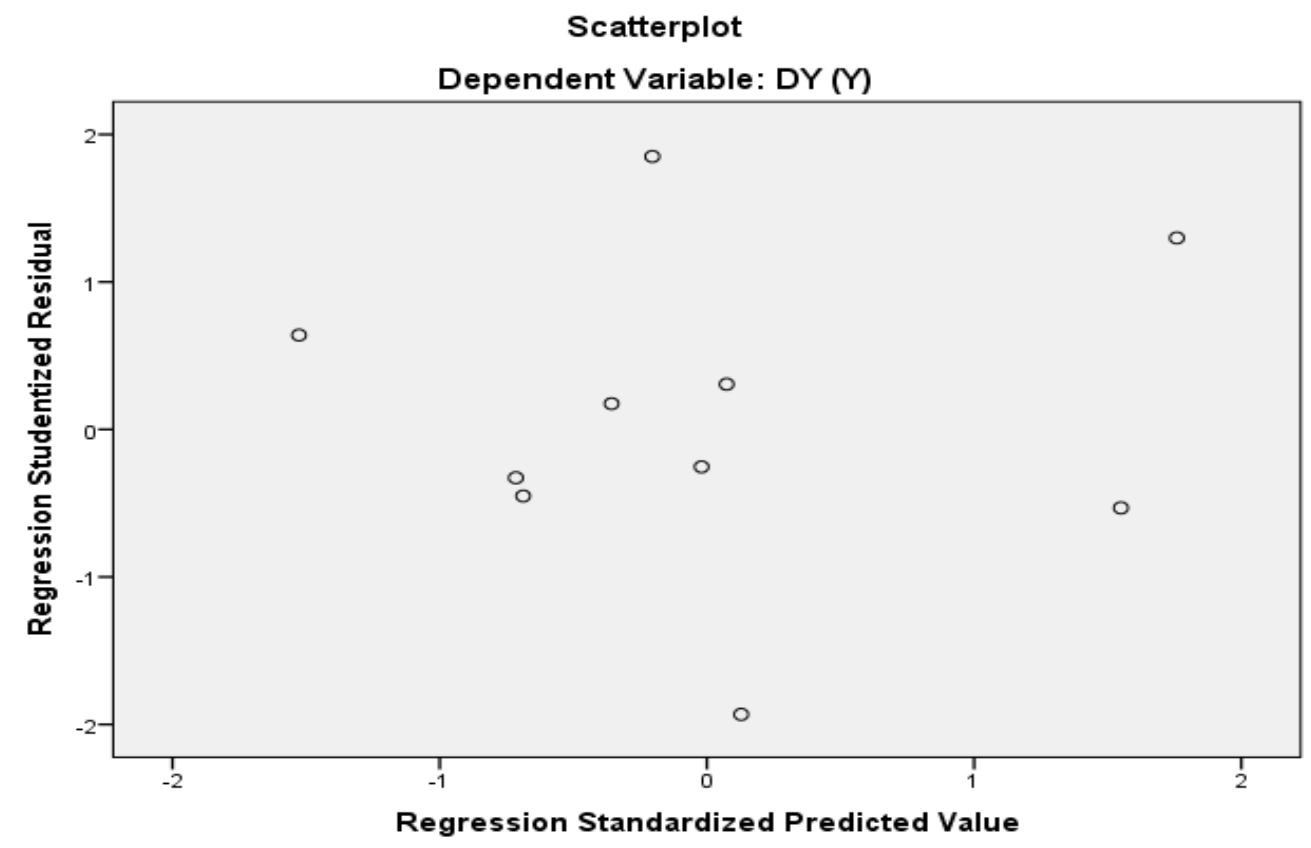

Gambar 1 Hasil Uji Heterokedastisitas

Sumber: Output SPSS versi 20

Berdasarkan grafik Scatterplot diatas, terlihat bahwa titik-titik menyebar dan tidak membentuk suatu pola teratur. Maka dapat disimpulkan bahwa tidak adanya indikasi heteroskedastisitas dan uji heteroskedastisitas terpenuhi.

\section{Uji Autokorelasi}

Uji Autokorelasi bertujuan untuk menguji apakah dalam model regresi linier berganda ada korelasi antara kesalahan penggunaan pada periode $\mathrm{t}$ dengan kesalahan pada periode sebelumnya (t-1). Teknik yang digunakan dalam penelitian ini adalah Run Test.

\section{Tabel 5. Uji Autokorelasi}

\section{Runs Test}

\begin{tabular}{|c|c|}
\hline & Unstandardized Residual \\
\hline Test Valuea & -.18553 \\
Cases $<$ Test Value & 5 \\
Cases $>$ Test Value & 5 \\
Total Cases & 10 \\
Number of Runs & 4 \\
Z & -1.006 \\
Asymp. Sig. (2-tailed) & .314 \\
\hline
\end{tabular}

a. Median

Sumber: hasil output SPSS for windows versi 20

Dasar pengambilan keputusan dalam uji Run Test yaitu jika nilai Asymp. Sig. (2-tailed) < dari 0.05 maka terdapat indikasi autokorelasi sedangkan jika nilai Asymp. Sig. (2-tailed) $>$ dari 0.05 maka tidak terdapat indikasi autokorelasi. Berdasarkan hasil pengujian autokorelasi diatas, 
diketahui nilai Asymp. Sig. (2-tailed) sebesar $0.314>$ dari 0.05. Maka dapat disimpulkan bahwa model tidak terdapat indikasi autokorelasi pada data yang di uji.

\subsection{Statistik Deskriptif}

Analisis deskriptif merupakan alat uji analisis yang digunakan untuk memaparkan atau menggambarkan data yang terkumpul agar mudah dipahami. Berikut analisis deskriptif mengenai Return on Capital Employed, Return on Equity dan Dividen Yield pada PT. Waskita Karya Tbk periode 2010-2019.

Tabel 6. Statistik Deskriptif Return on Capital Employed, Return on Equity dan Dividen Yield PT. Waskita Karya, Tbk.

Descriptive Statistics

\begin{tabular}{|c|c|c|c|c|c|}
\hline & $\mathrm{N}$ & Minimum & Maximum & Mean & Std. Deviation \\
\cline { 2 - 6 } & Statistic & Statistic & Statistic & Statistic & Statistic \\
\hline ROCE (X1) & 10 & 1.71 & 44.68 & 16.5790 & 13.66356 \\
ROE (X2) & 10 & 3.53 & 27.73 & 16.0560 & 7.45971 \\
DY (Y) & 10 & 3.53 & 25.14 & 11.2880 & 7.07404 \\
Valid N & 10 & & & & \\
(listwise) & & & & & \\
\hline
\end{tabular}

Sumber: hasil output SPSS for windows versi 20

Berdasarkan tabel diatas, menunjukkan banyaknya jumlah data yang diteliti, dalam penelitian ini jumlah data yang diteliti adalah 10 dari setiap variabel yaitu Return on Capital Employed (ROCE), Return on Equity (ROE) dan Dividen Yield (DY). Return on Capital Employed (ROCE) memperoleh mean sebesar 16.5790 dan standar deviasi sebesar 13.66356 dengan nilai minimum sebesar 1.71 dan nilai maksimum sebesar 44.68. Sedangkan Return on Equity (ROE) memperoleh mean sebesar 16.0560 dan standar deviasi sebesar 7.45971 dengan nilai minimum sebesar 3.53 dan nilai maksimum sebesar 27.73. Untuk Dividen Yield (DY) memperoleh mean sebesar 11.2880 dan standar deviasi sebesar 7.07404 dengan nilai minimum sebesar 3.53 dan nilai maksimum 25.14 .

\subsection{Pengaruh Return on Capital Employed (ROCE) Terhadap Dividend Yield (DY) PT. Waskita Karya, Tbk.}

Return on Capital Employed (ROCE) merupakan rasio yang digunakan untuk menentukan profitabilitas perusahaan dan efisiensi modal yang diterapkan. Rasio ini pun menampilkan kemampuan perusahaan dalam menghasilkan laba dari semua modal yang dipekerjakannya. Berdasarkan hasil analisis, dapat diketahui bahwa Return on Capital Employed (ROCE) terhadap Dividen Yield (DY) pada PT. Waskita Karya, Tbk. berpengaruh signifikan secara parsial. Hasilnya dapat dilihat pada analisis regresi, hasil uji korelasi pearson product moment, uji koefisien determinasi, dan uji t. Hasil uji regresi linear sederhana menunjukkan hasil berikut ini: 
Tabel 7. Analisis Regresi Linier Sederhana Return on Capital Employed terhadap Dividen Yield PT. Waskita Karya,Tbk.

Coefficients ${ }^{a}$

\begin{tabular}{|cc|c|c|c|c|c|}
\hline \multicolumn{2}{|c|}{ Model } & \multicolumn{2}{|l|}{ Unstandardized Coefficients } & $\begin{array}{c}\text { Standardized } \\
\text { Coefficients }\end{array}$ & $\mathrm{t}$ & \multirow{2}{*}{ Sig. } \\
\cline { 3 - 5 } & (Constant) & 4.690 & 2.464 & & \\
\hline \multirow{2}{*}{1} & B & .117 & .769 & 3.399 & .093 \\
& ROCE (X1) & .398 & .009 \\
\hline
\end{tabular}

a. Dependent Variable: DY (Y)

Sumber: hasil output SPSS for windows versi 20

Berdasarkan tabel regresi sederhana di atas, yaitu konstanta a sebesar 4.690 dan koefisien b sebesar 0.398. Berdasarkan hasil tersebut maka diperoleh persamaan regresi sebagai berikut:

$$
\mathrm{Y}=\mathrm{a}+\mathrm{bX}_{1}
$$

\section{Dividen Yield $(\mathrm{DY})=4,690+0,398$ Return on Capital Employed $(\mathrm{ROCE})$}

Berdasarkan persamaan regresi linier sederhana tersebut, diperoleh hasil nilai konstanta $(\alpha)$ yaitu 4,690 menunjukkan bahwa nilai Dividen Yield pada saat Return on Capital Employed bernilai nol atau tetap dan Dividen Yield bernilai positif, yaitu sebesar 4.690. Selanjutnya, variabel Return on Capital Employed (ROCE) memiliki nilai koefisien sebesar 0,398 artinya setiap kenaikan Return on Capital Employed (ROCE) sebesar satu-satuan maka akan diikuti dengan kenaikan Dividen Yield sebesar 0.398. Koefisien regresi b bernilai positif, artinya telah terjadi hubungan antara Return on Capital Employed (ROCE) dan Dividen Yield. (DY). Semakin tinggi nilai Return on Capital Employed (ROCE) maka Dividen Yield (DY) akan meningkat.

Selanjutnya, untuk menunjukkan keeratan hubungan antara Return on Capital Employed (ROCE) terhadap Dividen Yield (DY), maka akan dianalisis dengan metode perhitungan statistik yaitu korelasi Pearson Prodoct Moment . Berikut hasil perhitungan korelasi:

Tabel 8. Analisis Korelasi Pearson Product Moment Return on Capital Employed terhadap Dividen Yield PT. Waskita Karya,Tbk.

Correlations

\begin{tabular}{|c|c|c|c|}
\hline & & $\mathrm{ROCE}(\mathrm{X} 1)$ & $\mathrm{DY}(\mathrm{Y})$ \\
\hline & Pearson Correlation & 1 & .769 \\
\hline ROCE (X1) & Sig. (2-tailed) & & .009 \\
\hline \multirow{4}{*}{ DY (Y) } & $\mathrm{N}$ & 10 & 10 \\
\hline & Pearson Correlation & .769 & 1 \\
\hline & Sig. (2-tailed) & .009 & \\
\hline & $\mathrm{N}$ & 10 & 10 \\
\hline
\end{tabular}

Sumber: hasil output SPSS for windows versi 20

Berdasarkan hitungan SPSS V.20.0 di atas maka nilai korelasi yaitu 0.769 yang berada pada interval 0.60 - 0.799 artinya variabel Return on Capital Employed (ROCE) memiliki hubungan kuat dengan Dividen Yield (DY).

Mengacu pada hasil uji korelasi yang telah dilakukan sebelumnya, diketahui bahwa nilai $\mathrm{r}$ sebesar 0.769. Untuk mengetahui seberapa besar kontribusi pengaruh Return on Capital Employed 
(ROCE) terhadap Dividen Yield (DY) dapat diperkirakan dengan menggunakan hasil perhitungan SPSS versi 20 yaitu koefisien determinasi.

Tabel 9. Analisis Koefisien Determinasi Return on Capital Employed terhadap Dividen Yield PT. Waskita Karya, Tbk.

Model Summary

\begin{tabular}{|c|c|c|c|c|}
\hline Model & $\mathrm{R}$ & $\mathrm{R}$ Square & Adjusted R Square & Std. Error of the Estimate \\
\hline 1 & $.769^{\mathrm{a}}$ & .591 & .540 & 4.79922 \\
\hline
\end{tabular}

a. Predictors: (Constant), ROCE (X1)

b. Dependent Variable: DY (Y)

Sumber: hasil output SPSS for windows versi 20

Dari perhitungan tabel di atas menunjukkan R Square sebesar 0.591 atau 59.1\% merupakan koefisien determinasi yang mengartikan bahwa Return on Capital Employed (ROCE) terhadap Dividen Yield (DY) sebesar 59.1\% sisanya sebesar 40.9\% dipengaruhi oleh faktor lain di luar penelitian.

Dan terakhir, untuk mengetahui pengaruh Return on Capital Employed secara parsial terhadap Dividen Yield, dilakukan melalui uji t berikut hasil yang diperoleh:

Tabel 10. Analisis Uji t Return on Capital Employed terhadap Dividen Yield PT. Waskita Karya, Tbk.

Coefficients $^{\mathrm{a}}$

\begin{tabular}{|cc|c|c|c|c|c|}
\hline \multirow{2}{*}{ Model } & \multicolumn{2}{|c|}{$\begin{array}{c}\text { Unstandardized } \\
\text { Coefficients }\end{array}$} & $\begin{array}{c}\text { Standardized } \\
\text { Coefficients }\end{array}$ & Sig. \\
\cline { 3 - 5 } & B & Std. Error & Beta & & \\
\hline \multirow{2}{*}{1} & (Constant) & 4.690 & 2.464 & & 1.903 & .093 \\
& ROCE (X1) & .398 & .117 & .769 & 3.399 & .009 \\
\hline
\end{tabular}

a. $\quad$ Dependent Variable: DY (Y)

Sumber: hasil output SPSS for windows versi 20

Berdasarkan hasil SPSS for Windows V.20.0 di atas, diperoleh thitung sebesar 3.999. Sedangkan tabel dengan $\mathrm{df}=10-2=8$ dengan tingkat signifikansi sebesar $5 \%$ atau 0.05 , maka diperoleh $t_{\text {tabel }}$ sebesar 2.306. Hal ini memenuhi syarat $t_{\text {hitung }}>t_{\text {tabel }}$ yakni $3.999>2.306$ maka $_{a}$ diterima dan $\mathrm{H}_{\mathrm{o}}$ ditolak, artinya Return on Capital Employed berpengaruh signifikan terhadap Dividen Yiled pada PT. Waskita Karya, Tbk.

Peneliti tidak menemukan penelitian terdahulu yang sama persis dengan penelitian ini, dengan demikian penelitian ini dapat menjadi temuan awal bahwa Return on Capital Employed (ROCE) menjadi salah satu faktor yang mempengaruhi dividend yield pada PT. Waskita Karya, Tbk. Selain itu, hasil penelitian ini dapat menjadi kerangka acuan bagi perusahaan lain yang sejenis atau dalam sektor yang sama untuk menjadi pertimbangan dividend yield. Dan penelitian ini akan berimplikasi bagi PT. Waskita Karya, Tbk. untuk selalu meningkatkan Return on Capital Employed agar berpengaruh terhadap tingginya dividend yield.

\subsection{Pengaruh Return on Equity (ROE) Terhadap Dividend Yield (DY) pada PT. Waskita Karya, Tbk.}

Return on Equity (ROE) merupakan rasio profitabilitas yang digunakan untuk mengukur kemampuan perusahaan dalam pengembalian investasi bagi pemegang saham. Pertumbuhan angka perolehan rasio Return on Equity (ROE) yang tinggi menandakan bahwa suatu perusahaan 
dapat menghasilkan keuntungan yang besar bagi investor. Selain menghasilkan keuntungan yang besar bagi investor, pertumbuhan Return on Equity (ROE) yang tinggi menunjukkan bahwa semakin efisien dan efektif perusahaan dalam mengelola modalnya. Berdasarkan hasil analisis, dapat diketahui bahwa Return on Equity (ROE) terhadap Dividen Yield (DY) pada PT. Waskita Karya, Tbk. berpengaruh signifikan secara parsial. Hasilnya dapat dilihat pada analisis regresi, hasil uji korelasi pearson product moment, uji koefisien determinasi, dan uji t. Hasil uji regresi linear sederhana menunjukkan hasil berikut ini:

Tabel 11. Analisis Regresi Linier Sederhana Return on Equity terhadap Dividen Yield PT. Waskita Karya, Tbk.

Coefficients $^{\text {a }}$

\begin{tabular}{|cc|c|c|c|c|c|}
\hline \multirow{2}{*}{ Model } & \multicolumn{2}{|c|}{$\begin{array}{c}\text { Unstandardized } \\
\text { Coefficients }\end{array}$} & $\begin{array}{c}\text { Standardized } \\
\text { Coefficients }\end{array}$ & \multirow{2}{*}{ Sig. } \\
\cline { 3 - 5 } & B & Std. Error & Beta & & \\
\hline \multirow{2}{*}{1} & (Constant) & -.887 & 3.533 & & -.251 & .808 \\
& ROE (X2) & .758 & .201 & .800 & 3.767 & .005 \\
\hline
\end{tabular}

Sumber: hasil output SPSS for windows versi 20

Berdasarkan tabel regresi sederhana di atas, yaitu konstanta a sebesar -0,887 dan koefisien b sebesar $\mathbf{0 , 7 5 8}$. Berdasarkan hasil tersebut maka diperoleh persamaan regresi sebagai berikut:

$$
\mathrm{Y}=\mathrm{a}+\mathrm{bX}_{2}
$$

\section{Dividen Yield $(\mathrm{DY})=-0,887+0,758$ Return on Equity $(\mathrm{ROE})$}

Berdasarkan persamaan regresi linier sederhana tersebut, diperoleh hasil, nilai konstanta ( $\alpha$ ) yaitu -0,887 menunjukkan bahwa nilai Dividen Yield pada saat Return on Equity (ROE) bernilai 0 atau tetap maka Dividen Yield bernilai negatif yaitu sebesar -0,887.

Selanjutnya, variabel Return on Equity (ROE) memiliki nilai koefisien sebesar 0,398 artinya setiap kenaikan Return on Equity (ROE) sebesar satu-satuan maka akan diikuti dengan kenaikan Dividen Yield sebesar 0,758. Koefisien regresi b bernilai positif, artinya telah terjadi hubungan positif antara Return on Equity (ROE) dan Dividen Yield. (DY) Semakin tinggi nilai Return on Equity (ROE) maka Dividen Yield (DY) akan meningkat.

Selanjutnya, untuk menunjukkan keeratan hubungan antara Return on Equity (ROE) terhadap Dividen Yield (DY), maka selanjutnya akan dianalisis dengan metode perhitungan statistic yaitu korelasi.

Tabel 12. Analisis Korelasi Pearson Product Moment Return on Equity terhadap Dividen Yield PT. Waskita Karya, Tbk. Correlations

\begin{tabular}{|cc|c|c|}
\hline & & DY $(\mathrm{Y})$ & ROE (X2) \\
\hline \multirow{2}{*}{ DY (Y) } & Pearson Correlation & 1 & .800 \\
& Sig. (2-tailed) & & .005 \\
$\mathrm{~N}$ & 10 & 10 \\
& Pearson Correlation & .800 & 1 \\
ROE (X2) & Sig. (2-tailed) & .005 & 10 \\
& $\mathrm{~N}$ & 10 & \\
\hline
\end{tabular}

Sumber: hasil output SPSS for windows versi 20 
Berdasarkan hitungan SPSS versi 20 di atas maka nilai korelasi yaitu 0.800 yang berada pada interval 0.80-1.000 artinya variabel Return on Equity (ROE) memiliki hubungan sangat kuat dengan Dividen Yield (DY).

Mengacu pada hasil berikut, hasil uji korelasi yang telah dilakukan sebelumnya, diketahui bahwa nilai r sebesar 0.800. Untuk mengetahui seberapa besar pengaruh Return on Equity (ROE) terhadap Dividen Yield (DY) dapat diperkirakan dengan menggunakan hasil perhitungan SPSS versi 20 yaitu koefisien determinasi, berikut hasil yang didapatkan:

Tabel 13. Analisis Koefisien Determinasi Return on Equity terhadap Dividen Yield PT.

Waskita Karya, Tbk.

Model Summary

\begin{tabular}{|c|c|c|c|c|}
\hline Model & $\mathrm{R}$ & R Square & Adjusted R Square & Std. Error of the Estimate \\
\hline 1 & $.800^{\mathrm{a}}$ & .639 & .594 & 4.50547 \\
\hline
\end{tabular}

Predictors: (Constant), ROE (X2)

Sumber: hasil output SPSS for windows versi 20

Dari perhitungan tabel di atas menunjukkan $\mathrm{R}$ Square sebesar 0.639 atau 63.9\% merupakan koefisien determinasi yang mengartikan bahwa Return on Equity (ROE) terhadap Dividen Yield (DY) sebesar 63.9\% sisanya sebesar 36.1\% dipengaruhi oleh faktor lain di luar penelitian.

Untuk mengetahui pengaruh Return on Equity s(ROE) secara parsial terhadap Dividen Yield, dilakukan dengan uji t.

Tabel 14. Analisis Uji t Return on Equity terhadap Dividen Yield PT. Waskita Karya, Tbk.

Coefficients $^{\mathrm{a}}$

\begin{tabular}{|cc|c|c|c|c|c|}
\hline \multirow{2}{*}{ Model } & \multicolumn{2}{|c|}{$\begin{array}{c}\text { Unstandardized } \\
\text { Coefficients }\end{array}$} & $\begin{array}{c}\text { Standardized } \\
\text { Coefficients }\end{array}$ & \multirow{2}{*}{ T } & \\
\cline { 3 - 5 } & B & Std. Error & Beta & & \\
\cline { 3 - 5 } 1 & (Constant) & -.887 & 3.533 & & -.251 & .808 \\
& ROE (X2) & .758 & .201 & .800 & 3.767 & .005 \\
\hline
\end{tabular}

Dependent Variable: DY (Y)

Sumber: hasil output SPSS for windows versi 20

Berdasarkan SPSS versi 20 di atas, diperoleh thitung sebesar 3.767. Sedangkan tabel dengan $\mathrm{df}=10-2=8$ dengan tingkat signifikansi sebesar 5\% atau 0.05, maka diperoleh $t_{\text {tabel }}$ sebesar 2.306. Hal ini memenuhi syarat thitung $>$ tabel yakni $3.767>2.306$ maka $H_{a}$ diterima dan $H_{\circ}$ ditolak, artinya Return on Equity berpengaruh signifikan terhadap Dividen Yield pada PT. Waskita Karya, Tbk.

Hasil penelitian ini merupakan temuan awal yang diteliti, peneliti tidak dapat menemukan penelitian serupa yang dapat menjadi kerangka acuan. Sehingga penelitian ini berimplikasi pada PT. Waskita Karya, Tbk. bahwa Return on Equity berpengaruh terhadap peningkatan Dividen Yield. Selain itu juga penelitian ini dapat menjadi bahan pertimbangan bagi perusahaan lain yang sejenis untuk memperhatikan ROE mereka, terakhir penelitian ini dapat menjadi kerangka acuan bagi peneliti selanjutnya yang akan mengembangkan penelitian yang sama. 


\subsection{Pengaruh Return on Capital Employed (ROCE) dan Return on Equity (ROE) Terhadap Dividend Yield (DY) pada PT. Waskita Karya, Tbk.}

Dividen Yield (DY) merupakan rasio yang menghitung keuntungan dari Dividen Per Share dibagi dengan Market Price yang dinyatakan dalam bentuk presentase. Investor akan berusaha menginvestasikan dananya dalam bentuk saham ke dalam perusahaan yang menghasilkan Dividen Yield (DY) yang tinggi. Semakin tinggi Dividen Yield (DY) akan berdampak pada pengembalian yang tinggi juga. Maka dari itu, tentunya para investor menginginkan pengembalian saham yang besar dengan melihat perolehan presentase Dividen Yield (DY) yang ada pada suatu perusahaan.

Dividen Yield (DY) yang tinggi tentu dipengaruhi oleh berbagai faktor, penelitian ini menduga bahwa Return on Capital Employed (ROCE) dan Return on Equity (ROE) secara bersamaan memiliki pengaruh dalam meningkatkan Dividend Yield. Pada penelitian secara parsial, ROCE dan ROE terbukti memiliki pengaruh yang kuat dalam meningkatkan dividen yield. Menurut hemat peneliti, pendapatan yang baik adalah pendapatan yang memiliki lebih sedikit hutang untuk dibayarkan, sehingga dari total aset yang ada berkontribusi besar dalam meningkatkan pendapatan. Kemudian, modal yang terkelola dengan baik maka akan menghasilkan laba yang tinggi sehingga juga berdampak pada tingkat pengembalian dari saham investor yang tinggi pula.

Hasilnya dapat dilihat pada analisis regresi, hasil uji korelasi pearson product moment, uji koefisien determinasi, dan uji F. Hasil uji regresi berganda menunjukkan hasil berikut ini:

Tabel 15. Analisis Regresi Linier Berganda Return on Capital Employed dan Return on Equity terhadap Dividen Yield PT. Waskita Karya, Tbk.

Coefficients $^{\text {a }}$

\begin{tabular}{|c|c|c|c|c|c|c|}
\hline & \multirow[t]{2}{*}{ Model } & \multicolumn{2}{|c|}{$\begin{array}{c}\text { Unstandardized } \\
\text { Coefficients }\end{array}$} & $\begin{array}{l}\text { Standardized } \\
\text { Coefficients }\end{array}$ & \multirow[t]{2}{*}{$\mathrm{T}$} & \multirow[t]{2}{*}{ Sig. } \\
\hline & & B & Std. Error & Beta & & \\
\hline & (Constant) & .440 & 4.523 & & .097 & .925 \\
\hline 1 & $\mathrm{ROCE}(\mathrm{X} 1)$ & .537 & .482 & .566 & 1.114 & .302 \\
\hline & ROE (X2) & .135 & .263 & .260 & .512 & .624 \\
\hline
\end{tabular}

a. Dependent Variable: DY (Y)

Sumber: hasil output SPSS for windows versi 20

Berdasarkan tabel regresi berganda di atas, yaitu konstanta a sebesar 0.440, b1 sebesar 0.135 dan b2 sebesar 0.537. Berdasarkan hasil tersebut maka diperoleh persamaan regresi linier berganda sebagai berikut:

$$
\begin{gathered}
\mathrm{Y}=\mathrm{a}+\mathrm{b}_{1} \mathrm{X}_{1}+\mathrm{b}_{2} \mathrm{X}_{2} \\
\text { Dividen Yield }(\mathrm{DY})=0.440+0.135 \text { Return on Capital Employed }(\mathrm{ROCE})+0.537 \\
\text { Return on Equity }(\mathrm{ROE})
\end{gathered}
$$

Berdasarkan persamaan regresi linier berganda tersebut, diperoleh hasil, nilai konstanta ( $\alpha$ ) yaitu 0.440 menunjukkan bahwa nilai Dividen Yield pada saat Return on Capital Employed dan Return on Equity bernilai 0 (nol) dan Dividen Yield bernilai positif, yaitu sebesar 0.440 . Koefisien regresi b1 untuk Return on Capital Employed (ROCE) bernilai positif sebesar 0.135, artinya setiap kenaikan Return on Capital Employed (ROCE) sebesar satu-satuan maka akan diikuti dengan kenaikan Dividen Yield (DY) sebesar 0.135. Koefisien regresi b1 bernilai positif, artinya telah terjadi hubungan antara Return on Capital Employed (ROCE) dan Dividen Yield (DY). Semakin 
tinggi nilai Return on Capital Employed (ROCE) maka Dividen Yield (DY) akan meningkat. Selanjutnya, Koefisien regresi b2 untuk Return on Equity (ROE) bernilai positif sebesar 0.537, menunjukkan bahwa setiap kenaikan Return on Equity (ROE) sebesar satu-satuan maka akan menaikkan Dividen Yield (DY) sebesar 0.537. Koefisien regresi b2 bernilai positif, artinya telah terjadi hubungan antara Return on Equity (ROE) dan Dividen Yield (DY). Semakin tinggi nilai Return on Equity (ROE) maka Dividen Yield (DY) akan meningkat.

Kemudian, untuk menunjukkan keeratan hubungan antara Return on Capital Employed (ROCE) dan Return on Equity (ROE) terhadap Dividen Yield (DY), maka selanjutnya akan dianalisis dengan metode perhitungan statistic yaitu korelasi.

Tabel 16. Analisis Korelasi Berganda Return on Capital Employed dan Return on Equity terhadap Dividen Yield PT. Waskita Karya, Tbk.

Model Summary

\begin{tabular}{|c|c|c|c|c|}
\hline Model & $\mathrm{R}$ & $\mathrm{R}$ Square & Adjusted R Square & Std. Error of the Estimate \\
\hline 1 & $.808^{\mathrm{a}}$ & .652 & .553 & 4.72872 \\
\hline
\end{tabular}

a. Predictors: (Constant), ROE (X2), ROCE (X1)

Sumber: hasil output SPSS for windows versi 20

Berdasarkan hitungan SPSS versi 20 di atas maka nilai korelasi yaitu 0.808 yang berada pada interval 0.80 - 1.000 artinya variabel Return on Capital Employed (ROCE) dan Return on Equity (ROE) memiliki hubungan sangat kuat dengan Dividen Yield (DY).

Mengacu pada hasil uji korelasi yang telah dilakukan sebelumnya, diketahui bahwa nilai $\mathrm{r}$ sebesar 0.808. Untuk mengetahui seberapa besar pengaruh Return on Capital Employed (ROCE) dan Return on Equity (ROE) terhadap Dividen Yield (DY) dapat diperkirakan dengan menggunakan hasil perhitungan SPSS versi 20.

Tabel 17. Analisis Koefisien Determinasi Return on Capital Employed dan Return on Equity terhadap Dividen Yield PT. Waskita Karya, Tbk.

Model Summary

\begin{tabular}{|c|c|c|c|c|}
\hline Model & $\mathrm{R}$ & $\mathrm{R}$ Square & Adjusted R Square & Std. Error of the Estimate \\
\hline 1 & $.808^{\mathrm{a}}$ & .652 & .553 & 4.72872 \\
\hline
\end{tabular}

a. Predictors: (Constant), ROCE (X1), ROE (X2)

Sumber: hasil output SPSS for windows versi 20

Dari perhitungan tabel di atas menunjukkan $\mathrm{R}$ Square sebesar 0.652 atau $65.2 \%$ merupakan koefisien determinasi yang mengartikan bahwa Return on Capital Employed (ROCE) dan Return on Equity (ROE) terhadap Dividen Yield (DY) sebesar 65.2\% sisanya sebesar 34.8\% dipengaruhi oleh faktor lain di luar penelitian.

Terakhir, untuk melihat pengaruh secara simultan yang ditimbulkan oleh ROCE dan ROE terhadap Dividend Yield secara simultan, maka dianalisis menggunakan Uji F. Hasil uji F menunjukkan: 
Tabel 18. Analisis Uji F Return on Capital Employed(ROCE) dan Return on Equity (ROE) terhadap Dividen Yield (DY) PT. Waskita Karya, Tbk.

ANOVAa

\begin{tabular}{|c|c|c|c|c|c|c|}
\hline \multicolumn{1}{|c|}{ Model } & Sum of Squares & Df & Mean Square & F & Sig. \\
\hline \multirow{2}{*}{1} & Regression & 293.853 & 2 & 146.927 & 6.571 & $.025^{\mathrm{b}}$ \\
& Residual & 156.526 & 7 & 22.361 & & \\
& Total & 450.379 & 9 & & & \\
\hline
\end{tabular}

a. Dependent Variable: DY (Y)

b. Predictors: (Constant), ROE (X2), ROCE (X1)

Sumber: hasil output SPSS for windows versi 20

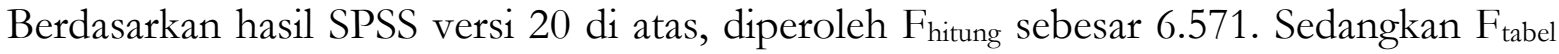
dengan (k-1) (n-k) dengan tingkat signifikansi sebesar $5 \%$ atau 0.05 , maka diperoleh $F_{\text {tabel }}$ sebesar 4.74. Hal ini memenuhi syarat $F_{\text {hitung }}>F_{\text {tabel }}$ yakni $6.571>4.74$ maka $\mathrm{H}_{\mathrm{a}}$ diterima dan $\mathrm{H}_{\mathrm{o}}$ ditolak, artinya Return on Capital Employed dan Return on Equity berpengaruh signifikan terhadap Dividen Yield secara simultan pada PT. Waskita Karya, Tbk. Pada akhirnya penelitian ini menemukan bahwa pada PT. Waskita Karya, Tbk., dividend yield sepanjang tahun 2010 sampai dengan 2019 dipengaruhi oleh Return on Capital Employed dan Return on Equity dengan kekuatan hubungan yang sangat kuat dan kontribusi pengaruh 65,2\%.

Berdasarkan hasil penelitian yang telah diuraikan diatas, maka dapat diketahui baik secara parsial dan simultan Return on Capital Employed (ROCE) dan Return on Equity (ROE) memiliki pengaruh signifikan terhadap Dividend Yield (DY). Dimana dari hasil penelitian itu, ditemukan dari setiap kenaikan Return on Capital Employed (ROCE) dan Return on Equity (ROE) akan diikuti dengan kenaikan Dividend Yield (DY). Tingginya persentase yang dihasilkan oleh Dividend Yield (DY), tentunya akan berpengaruh pula terhadap return saham yang akan diperoleh investor. Perolehan return saham ini akan mendorong para investor untuk melakukan investasi pada perusahaan

\section{$4 \quad$ Kesimpulan}

Berdasarkan pembahasan yang telah diuraikan dapat disimpulkan bahwa Return on Capital Employed (ROCE) secara parsial berpengaruh terhadap Dividend Yield (DY) dengan kontribusi pengaruh 59,1\%. Kemudian, Return on Capital Equity (ROE) secara parsial berpengaruh terhadap Dividen Yield (DY) dengan kontribusi pengaruh 63,9\%. Secara simultan, Return on Capital Employed (ROCE) dan Return on Equity (ROE) berpengaruh terhadap Dividen Yield (DY) berdasarkan perhitungan analisis korelasi sebesar 0,808 yang artinya Return on Capital Employed (ROCE) dan Return on Equity (ROE) memiliki hubungan sangat kuat terhadap Dividen Yield (DY). Adapun dalam perhitungan koefisien determinasi Return on Capital Employed (ROCE) dan Return on Equity (ROE) mempengaruhi Dividen Yield (DY) sebesar 65.2\% dimana sisanya dipengaruhi oleh faktor lain yang tidak diteliti di penelitian ini. Selain itu, dalam pengujian hipotesis menghasilkan $f_{\text {hitung }}>\mathrm{f}_{\text {tabel }}$ yakni $6.571>4.74$. Penelitian ini berimplikasi pada PT. Waskita Karya, Tbk. bahwa Return on Capital Employed (ROCE) dan Return on Equity (ROE) sudah selayaknya terus ditingkatkan karena menunjukkan pendapatan bersih dan modal yang dikelola dengan baik, sehingga berpengaruh terhadap meningkatkan dividend yield. Selain itu, penelitian selanjutnya dapat menggunakan penelitian ini sebagai kerangka acuan, dan mengembangkannya. 


\section{Referensi}

Ang, R. (2010). Buku Pintar Pasar Modal Indonesia. Jakarta: Mediasoft Indonesia.

Billah, Z. I., \& Jinnani, N. F. (2020). Faktor-Faktor yang Berpengaruh Terhadap Harga Saham Syariah PT. Wijaya Karya, Tbk., dan PT. Aneka Tambang, Tbk. Finansha-Journal of Sharia Financial Management, 3.

Carlo Aldo, M. (2014). Pengaruh Return on Equity, Dividend Payout Ratio, dan Price to Earnings Ratio pada Return Saham. E-Jurnal Akuntansi Udayana, 151.

Egam, G. E., Ilat, V., \& Pangerapan, S. (2017). Pengaruh Return on Asset (ROA), Return on Equity (ROE), Net Profit Margin (NPM) dan Earning Per Share (EPS) terhadap Harga Saham Perusahaan yang tergabung dalam Indeks LQ45 di Bursa Efek Indonesia periode tahun 2013-2015. E-Journal Unsrat, 108.

Hendarata, A. S. (2018). Pengaruh Dividend Yield terhadap Return Saham serta Mediasi Price Earning Ratio dan Dividend Payout Ratio pada Pengaruh Earning Per Share terhadap Return Saham (Studi Empiris pada Perusahaan Milik Negara (BUMN) yang Listing di BEI periode 2014-2016). Skripsi, 33.

Herlina. (2013). Pengaruh Return on Capital Employed (ROCE), Return on Asset (ROA), dan Return on Equity (ROE) terhadap Earnings Per Share pada Perusahaan Manufaktur yang Terdaftar di Bursa Efek Indonesia . Skeripsi, 4.

Khuniarji, A. W. (2013). Hubungan Kebijakan Dividen (Dividend Payout Ratio dan Dividend

Yield) terhadap Volatilitas Harga Saham di Perusahaan-Perusahaan yang Terdaftar di Bursa Efek Indonesia. Skripsi, 9.

Prakoso, P. G., \& Chabachib, M. (2016). Analisis Pengaruh Current Ratio, Size, Debt to Equity

Ratio, dan Total Asset Turnover terhadap Dividend Yield dengan Return on Asset sebagai Variabel Intervening. Diponegoro Journal Of Marketing, 3.

Rahmadewi, P. W., \& Abudanti, N. (2018). Pengaruh EPS, PER, CR dan ROE terhadap Harga Saham di Bursa Efek Indonesia. Jurnal Manajemen Unud, 10.

Sudjana. (2005). Metoda Statistika. Bandung: PT. Tarsito Bandung.

Suteja, J., \& Gunardi, A. (2016). Manajemen Investasi dan portofolio. Bandung: PT. Refika Aditama. 